\title{
The Effectiveness of Using the Cooperative Language Learning Approach to Enhance EFL Writing Skills among Saudi University Students
}

\author{
Montasser Mohamed AbdelWahab Mahmoud \\ College of Languages and Translation, Al-Imam University, Riyadh, Saudi Arabia
}

\begin{abstract}
Cooperative language learning (CLL) approach was used to encourage second-year university students at the college of languages and translation, at Al-Imam University to learn from their peers so that they could develop their writing skills. Students in CLL-based groups were trained to be more responsible for their learning through developing their personal interaction as well as their linguistic competence in a more relaxed social context. This treatment included sophomore students enrolled in EN 211 course in the second semester of 2013 academic year. Two instruments were used in this study; a pre-post writing test, and an attitude questionnaire. The pre- and post- scores from the test were calculated for descriptive statistics and compared using a Wilcoxon Test. The process of evaluating students' writings focused mainly on analyzing their mistakes with regard to spelling, using of vocabulary, grammar, punctuation as well as coherence. The findings revealed that the students' scores in writing were higher for the post-test than the pre-test at the significance level of .001 after being subject to this kind of treatment. However, it must be stated that the degree of improvement was not extremely high as students still made some mistakes with regard to the previously mentioned points. As for the attitude scale, the results obtained proved that the students developed positive attitudes towards using the cooperative learning approach to develop language skills in general and to develop their writing skills in particular.
\end{abstract}

Index Terms - CLL approach, CLL-based groups, EFL writing, attitude

\section{INTRODUCTION}

There is no doubt that Cooperative Learning can be used as an effective approach to encourage students to work together as one team inside the class. According to Hirst and Slavik (2003) active participation in discussing various viewpoints on a certain topic could be activated through the use of cooperative learning approach inside the classroom. Lee (203) also asserted that students' participation in hand-on activities can be enhanced through the use of small group activities. Furthermore, assisting peers to learn through explaining subject content to one another has been positively correlated with academic achievement (Depaz \& Moni, 2008). In fact, the spirit of competitiveness and the domination of individualism may be reduced and lessened through adopting the approach of cooperative learning that provides a supportive learning environment for students in which they can acquire and exchange ideas, information and knowledge. In writing class, small groups can be used to create communication, interpersonal and team skills as members of each group do not have the same background or ability in EFL writing. This sort of variety helps students within each group support their peers as they can complement each other's strengths and weaknesses in EFL writing; some of them may have strong background in vocabulary or grammar while other students may have good background about the topic they are discussing. Following this way, low level students can benefit from their strong-level peers' feedback with regard to their grammatical, vocabulary, punctuation and spelling mistakes, and at the same time good students will feel satisfied and proud that they had a significant role in helping their low level classmates. By using the cooperative language learning (CLL) approach, students could discuss, share ideas, and see how their peers think and react. Therefore, a more relaxing environment of learning can be rendered and more opportunities for students to produce better EFL writing can be provided.

\section{REVIEW OF LITERATURE}

In cooperative learning, students are generally divided into groups. In each group, three to five students share ideas, study and work together and negotiate meaning to develop a shared knowledge and achieve a certain objective or find a solution to a specific learning problem instead of working alone and competing with each other individually. The same issue was adopted by John (1997) who asserted that learners need to work together on a topic and help one another so that all could reach mutual success. According to Kagan (1994), cooperative learning would encourage learners to have higher achievement than competitive or individualistic learning as it offers learners opportunities that enable them to increase their self-esteem and to become more intrinsically motivated. Astin (1993) also highlighted the importance of using cooperative learning as an approach of learning that could play a vital role in increasing interaction among members of each group on one side and among the divided groups on the other side. Budd (2004) also stated that 
exercises used in cooperative learning, among small groups, could provide an adequate chance for students to analyze deeply the topic they discuss Similarly, White and Caminero (1995) pinpointed that cooperative learning helped students learn from each other. On the same hand, Biggs (1999) contended that the increasing number and diversity of the university population had a negative impact on the usefulness of the traditional lecture and tutorial. Therefore, Brookfield (1999 suggested using active learning strategies [such as cooperative learning] to increase the benefit for students and improve their chances for success. Herreid (2006) called for incorporating discussion activities such as Think/Pair/Share and Case Studies so as to help students develop their understanding and improve their overall attitudes. Hayashi (2005) asserted the importance of practicing writing among peers as an effective means to improve their writing skills.

Many pieces of research have supported the effectiveness of using cooperative learning approach in EFL classes so far. While some of these researches indicated that this approach could help students develop their English language skills, other studies focused on the effectiveness of using cooperative learning approach in developing their writing skills in particular(Cole, 2012, Elola and Oskoz, 2010, Wong et al. 2009, Mason, 2006; Chen, 2004; Atkinson, 2003, Mariam, 2004; Chandrika, 2001). The findings obtained from the previously stated studies enabled the researcher to build a strong and sound theoretical background about the use of the cooperative learning approach to develop and enhance students' writing skills. However, these studies have been mostly confined to writing in the secondary school setting within ESL writing classrooms. Undoubtedly, some of the previous studies focused on the use of CLL within tertiary writing classrooms, but more insights are still needed to show how this approach could be used in specific academic settings with respect to the concerns highlighted previously. In other words, while empirical evidence advocated the use of the CLL approach with various subject areas and different age groups, less is still known regarding the effectiveness of such an approach with regard to EFL not only ESL university level learners. Therefore, the focus of this study was on EFL writing within tertiary writing classrooms as English in Saudi Arabia is taught and used as a foreign language not as a second language.

The review of the literature revealed that the CLL approach could be used as a significant strategy in developing student's EFL writing skills and their attitudes towards using it. Atkinson (2003) stated that the use of the CLL approach to enhance EFL writing inside classroom is based on the argument that writing instruction in an EFL classroom is not only getting students to put pen to paper, but it also involves facilitating personal interaction among students as well as developing students' responses towards texts. Kim and Kim (2005) also highlighted the necessity of following the CLL approach instruction when students learn to write in this way so that students would be expected to generate, organize, and share their ideas in addition to taking care of the main components of the writing process such as vocabulary, spelling, purpose, target audience, and mechanics. All these components were put into consideration when selecting the small group activities inside the class. Second-year university students suffer from a lot of problems with regard to their writing skills especially in the five previously mentioned points. They need more active and interesting atmosphere in which they could enjoy more personal interaction rather than personal cognitive competence to be able to write effectively. It is supposed that working together in small groups could be a motivating factor to share ideas and get feedback by which they could correct themselves and achieve their purpose of writing effectively.

\section{STATEMENT OF THE PROBLEM}

In tertiary EFL writing classrooms, students face a lot of problems when trying to write an essay. These problems represent a great challenge that researchers should do their best to find a solution to them. It is commonly known that using traditional approaches to develop writing skills focuses mainly on accuracy and ignores to a great extent the process of writing itself. Therefore, the present study suggested that such problems can be solved if EFL writing is taught using the CLL approach as group writing discussions develop students' interpersonal and communication skills and help them decide on their purpose while writing. Moreover, the use of this approach ensures applying the steps of writing as students will be given adequate opportunities to brainstorm, share ideas, write a first draft, plan, organize, revise, and edit. Hence, there was a need to investigate the impact of the CLL approach on developing students' writing skills.

The need to conduct such a study arose from the researcher's work as an assistant professor at Al-Imam University, college of Languages and Translation. The researcher has been teaching writing courses to university students since 2010 and has found that essay writing needs a lot to be done effectively especially among Saudi University students who could not write well even after eleven years of learning English. The students' inability to write effectively may be due to three main factors, namely, their cognitive background which reflected their inability to develop interesting and thoughtful ideas, their linguistic deficiency which was represented in their errors with regard to spelling, capitalization, vocabulary and structure, and academic writing problems in designing and planning paragraphs cohesively. Such basic deficiencies were often detected during the researcher's teaching of writing courses. It has therefore been suggested that the CLL approach could be an effective method to overcome these problems. From the researcher's point of view, the cooperative learning approach could serve as an effective method to fulfill the needs of university learners as it could develop cooperation among students within each group and promote respect for their varied experiences and backgrounds. It could also provide students with adequate opportunities to think and talk together, and consequently they could share ideas about the writing requirements. Such a less-anxiety producing environment let students write 
with no fear of being subject to critical situation and it might create an interesting atmosphere in which the writing process would become less burdensome and less boring.

This study focused on the impact of using the CLL approach on developing EFL writing skills inside an EFL classroom. More specifically, the study attempted to answer the following questions:

1. To what extent was the CLL approach effective in developing second-year university students' writing skills?

2. What is the general attitude of the second-year university students towards the use of the CLL approach to enhance their EFL writing skills?

\section{OBJECTIVES OF THE RESEARCH}

1. To investigate the effectiveness of using the CLL approach in developing the writing skills of second-year university students enrolled in EN 211 course in the second semester of 2013 academic year at Al Imam University, college of languages and translation.

2. To examine the students' attitude towards using the CLL approach to enhance the writing skills of second-year university students enrolled in EN 211 course in the second semester of 2013 academic year at Al Imam University, college of languages and translation.

\section{ReSEARCH Methodology}

The current study adopted the one group pre-test, post-test design as the researcher had no chance to apply his study on other sections. Therefore the data were collected from one section (No.143) which contained 20 students (only fifteen students who completed to the end of the course) enrolled in a required EN 211 course of three credits in the second semester of 2013 academic year. The sample might seem small but it could give more specific and accurate results as there is a single selected group, which is section No.134, under observation, with a careful measurement being done before applying the treatment (the CLL approach) and then measuring after. This design has minimal internal validity, controlling only for selection of subject and experimental mortality but it has no external validity. The researcher did his best to overcome all kinds of threats to its internal validity.

\section{A. Instruments}

Two instruments were used to determine the effectiveness of using the CLL approach to develop students' writing skills. The first one was a pre-post writing test. The total score was 45 points. Time allotted for the writing test was 100 minutes. The validity of the test items were ensured by three TEFL experts. The contents for testing students included eight parts:

1) Write about a piece of clothing that is special to you.

2) Read the following paragraph and correct the three fragments and two run-on errors.

3) Write two supporting sentences for each of the following topic sentences.

4) Read the following paragraph below and cross out the sentences that do not support the topic sentence.

5) Write a thesis statement, describing the three categories for each of these topics.

6) To what extent does your college provide these opportunities? Write a three-paragraph essay expressing your opinion.

7) Read the following paragraph and answer the questions below it.

8) Read the following sentences, then number them in the order you think they occurred.

The second instrument was a 34 item questionnaire. It was developed based on the literature review conducted by the researcher. Some of the items were adopted from Brown's study (2008) and Farrah's study (2011) and then adapted to suit the current study. The researcher developed a questionnaire that could be used for examining students' attitudes towards using the CLL approach to enhance their EFL writing skills. The questionnaire consisted of 34 statements with a 3 point Likert scale, (agree, neutral and disagree). The 34-item questionnaire was distributed at the end of the second semester of the academic year 2012/2013 to the subjects of the study. The reliability coefficient of the questionnaire was tabulated. The Cronbach Alpha Coefficient of the questionnaire was $(r=0.88)$ that refers to a very high degree of internal consistency, and therefore it could offer a considerably reliable instrument.

\section{B. Samples and Locations}

The samples for the study included one group of EFL second-year students (20 students) from Al-Imam University, College of Languages and Translation. It was unavailable for the researcher to select other sections as he was responsible for teaching only one section.

\section{The Treatment}

From past experience in teaching writing courses, some students seemed to develop a negative attitude towards studying EFL writing so they used to cut the class as they were not able to catch up with others in class. To solve this problem, the CLL approach was of interest to the researcher due to its positive outcomes as mentioned earlier. The study was therefore conducted to see if this approach was effective in producing higher achievement with regard to writing or not. The students were divided into five groups consisting of four students per group who were asked to write 
essays together throughout the second semester of the academic year 2012/2013. Students were given general guidelines for the major points to be covered in their essay writings. In order to make sure that the students work effectively on such cooperative writing activities, the researcher explained to his students what is meant by co-operative writing and how they could make full use of this approach to enhance their writing skills. The students were given the right to choose their own group as well as a leader for each group. The group leader was responsible for managing and organizing the writing activities. Each group was given a letter (A, B, C, D, E) to judge the performance of each group concerning the writing activities. The numbers of the students inside each group reduced to be three instead of four as some students were not able to attend all classes. In some lectures, the students were asked to brainstorm ideas either by writing them in a list, a cluster or a two column design, and write the outline of their essays individually, and then work together in their own groups and compare their writing with that of the other students in the group. In other lectures, the students were asked to organize ideas, write the first draft, revise and give each other feedback. Students were encouraged to read aloud their writing outcome to other groups so that the five groups could benefit from each other. Students were given several topics to write about such as "Introducing Yourself to a Future Employer", "The Death Penalty", "Coed and Single-Sex Schools", "The Best Time to be Alive". Such topics were given to students to urge them to think and talk together. At the same time, they could share and exchange ideas with their group members. Problems in writing such as punctuation marks, spelling mistakes, grammatical structures were given much attention from the students as well as from the researcher. Furthermore, students were encouraged to give their comments and feedback to each other. Following the final completion of the writing tasks, the students were asked to fill out a questionnaire about their attitude towards the use of the CLL approach to enhance EFL writing skills to see whether or not the process improved their writing and their attitudes towards the cooperative writing activities.

An average of 15 students attended regularly a three-hour lecture session per week while the other five used to cut some of the classes so the researcher avoided referring to their results. The treatment was made in the following way:

1. The first one-hour lecture was devoted for explaining the way students were going to use the CLL approach inside the classroom. The pre-test was also given to students during the second two-hour lecture of the same week. The two lectures were on the second week of the semester as students were engaged in the process of registration on the first week.

2. Four weeks (eight lectures' sessions) were devoted to developing support skills for writing one paragraph essay (indentation, capitalization, quotation marks, formulating an outline)

3. Four weeks (eight lectures' sessions) were devoted for organizing and writing a three paragraph essay (An Introduction that includes a thesis statement, a body paragraph that includes either explanations, examples, statistics or facts, and a conclusion)

4. Four weeks (eight lectures' sessions) were devoted for dealing with a specific writing technique (comparing and contrasting data, Classification, Comparison and Contrast).

2. In week fourteen, students were given the post-test in the two-hour lecture and they were asked to complete an attitude questionnaire in the other one-hour lecture of the same week.

\section{The Lecture Format}

For the lecture format, the researcher used a combination of hand-outs and CLL activities that depended on the drills and activities included in their writing course, Reasons to Write. The treatment had been conducted over a period of 14 weeks. The groups within this section had been taught by the researcher. Each group was expected to complete an essay writing every week. They used to start with brain storming with its different forms, sharing ideas, drawing an outline, organizing ideas, making the first draft, revising, editing, and writing the final draft. They were also asked to read aloud their essays to the whole class and then given a score depending on the degree of accuracy they reached in their writing. In this way, they were highly stimulated and encouraged as the researcher observed that this motivating environment had a vital role in making the students enjoy doing writing tasks as they worked cooperatively to achieve a certain purpose. In this study, the researcher did his best to provide a relaxing environment and appropriate tasks for giving students equal opportunities. This was also accompanied by writing assignments which were in a class with the topics included in their writing course as well as their language level. These assignments were given to students to be done individually or in a group, and then marked by the researcher. Along these lines, students were given the chance to compare their current scores to the previous given ones so that they could check the improvement of the writing level during the treatment.

\section{Data Collection}

The obtained scores from the post-test were compared with the pre-test scores to show how students' writing skills improved. To learn how the students felt towards learning with this approach, an attitude questionnaire was distributed to students. The treatment was used with twenty students but five of them were not able to attend all classes or complete the course so all their degrees and grades were excluded from the final result. However, most students who regularly attended classes (15 students) appeared to be motivated and encouraged to complete the writing course and take the post test and the questionnaire.

\section{Data Analysis}

The data obtained from the tests were analyzed quantitatively using SPSS Program through descriptive and dependent Wilcoxon Test statistics. Also, the data from the attitude scale were analyzed and presented. 


\section{RESEARCH RESULTS}

a) As for the first question of the study, a Wilcoxon Signed Ranks Test was used to compare the mean scores of the students' answers on the pre/post- test. The test was used to find out the effectiveness of using the CLL approach to enhance students' EFL writing Skills. The following table compares the pre/posttest means for students concerning the writing test.

TABLE 1:

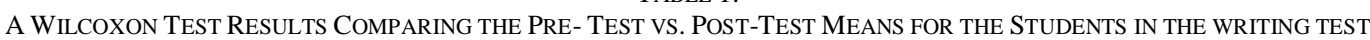

\begin{tabular}{|l|l|l|l|l|l|l|}
\hline & $N$ & Mini. & Maxi. & Mean & Std.Deviation & Sig. \\
\hline Pre- test & 15 & 11 & 33 & 21.80 & 6.516 & -3.415 \\
\hline Post-test & 15 & 20 & 42 & 33.33 & 6.543 & .001 \\
\end{tabular}

The results showed that the mean score of the post-test was higher than that of the pre-test. As evidenced by the significant difference at the level of .001, it clearly illustrated that the CLL approach used inside the classroom proved rather effective. The maximum score of students rose from 33 in the pre-test to be 42 in the post-test. To investigate accurately how the treatment was effective in developing students' writing skills, the following table compares the number and the percentage of students in the pre-posttest in detail.

TABLE 2:

A COMPARISON BETWEen THE NUMBER AND THE PERCENTAGE OF STUDENTS IN THE PRE-POST WRITING TEST

\begin{tabular}{|c|c|c|c|c|c|c|c|c|c|c|c|c|c|c|c|}
\hline & \multirow[t]{2}{*}{ No. } & \multicolumn{2}{|c|}{ Failed } & \multicolumn{2}{|c|}{ Passed } & \multicolumn{2}{|c|}{$\begin{array}{l}\text { From 50\% to } \\
59 \%\end{array}$} & \multicolumn{2}{|c|}{$\begin{array}{l}\text { From } 60 \% \text { to } \\
69 \%\end{array}$} & \multicolumn{2}{|c|}{$\begin{array}{l}\text { From } 70 \% \text { to } \\
79 \%\end{array}$} & \multicolumn{2}{|c|}{$\begin{array}{l}\text { From } 80 \% \text { to } \\
89 \%\end{array}$} & \multicolumn{2}{|c|}{$\begin{array}{l}\text { From } 90 \% \text { to } \\
100 \%\end{array}$} \\
\hline & & No. & Per. & No. & Per. & No. & Per. & No. & Per. & No. & Per. & No. & Per. & No. & Per. \\
\hline Pre & 15 & 9 & $60 \%$ & 6 & $40 \%$ & 2 & 13.3 & 2 & 13.3 & 2 & 13.3 & 0 & 0 & 0 & 0 \\
\hline Post & 15 & 1 & $6.2 \%$ & 14 & 93.8 & 1 & 6.6 & 3 & 20 & 4 & 26.6 & 3 & 20 & 3 & 20 \\
\hline
\end{tabular}

The results stated in the previous table showed clearly how the CLL approach was effective in developing students' writing skills. The total number of students who passed the pre-test was six but it rose to 14 in the posttest. The total percentage of successful students reached $93.8 \%$ as there was only one student who was not able to pass the writing test. This result reflected the effectiveness of using CLL approach to enhance students' EFL writing skills especially if it was compared to the percentage in the pretest which was 40\%. Examining the results included in the previous table showed that no student could get a mark over $79 \%$ while six students were able to get over $80 \%$. It was also noted that there was not a big change in the number or percentage of students who got from $50 \%$ to $69 \%$ in the pre-posttest. Such a result reflected that the CLL approach was not of a great value to them as their levels remained the same. This might have been due to their inability to mix effectively with their group or their lack of desire to share seriously in the small-based groups. As for those who got higher percentage in the posttest than the pre-test, it must be said that they appreciated the use of the CLL approach and found it effective as well as interesting. This was obvious in their care about every step and their interest in asking about every small details related to the application of this approach inside the classroom.

b) As for the second question of the study, the means and standard deviation was measured for all items included in the attitude questionnaire to know exactly how students felt about using the CLL approach to enhance their EFL writing skills. The following table showed the results obtained from distributing the attitude questionnaire on the students. 
TABLE 3:

MEANS AND STANDARD FOR ALL ITEMS IN THE QUESTIONNAIRE

\begin{tabular}{|c|c|c|c|c|}
\hline No & Statement & No. & $M$ & $S D$ \\
\hline 1 & The CLL approach develops students' awareness of writing skills & 15 & 1.53 & .743 \\
\hline 2 & The CLL approach improves interpersonal and team skills & 15 & 1.87 & .352 \\
\hline 3 & The CLL approach develops critical thinking skills & 15 & 1.27 & .799 \\
\hline 4 & The CLL approach provides chances to express ideas freely. & 15 & 1.80 & .414 \\
\hline 5 & The CLL approach provides more opportunities for students to participate in hands-on activities & 15 & 1.33 & .816 \\
\hline 6 & $\begin{array}{l}\text { The CLL approach develops students' responsibility not only for learning what is being taught, but } \\
\text { also for helping team mates learn. }\end{array}$ & 15 & 1.53 & .640 \\
\hline 7 & The CLL approach assists peers to learn through explaining subject content to one another & 15 & 1.67 & .617 \\
\hline 8 & The CLL approach saves time & 15 & 1.07 & .884 \\
\hline 9 & The CLL approach is a very worthwhile experience. & 15 & 1.40 & .910 \\
\hline 10 & The CLL approach can be used to stimulate students to acquire more knowledge. & 15 & 1.40 & .737 \\
\hline 11 & The CLL approach fosters exchange of ideas, information and experience. & 15 & 1.80 & .414 \\
\hline 12 & The CLL approach enhances performance in designing and organizing an essay. & 15 & 1.47 & .834 \\
\hline 13 & The CLL approach should be used in teaching all language skills. & 15 & 1.33 & .816 \\
\hline 14 & The CLL approach decreases competitiveness and individualism. & 15 & 1.60 & .737 \\
\hline 15 & The CLL approach increases students'self-esteem. & 15 & 1.13 & .834 \\
\hline 16 & The CLL approach offers students opportunities to become more intrinsically motivated. & 15 & 1.13 & .915 \\
\hline 17 & The CLL approach develops the spirit of confidence. & 15 & 1.47 & .834 \\
\hline 18 & The CLL approach is effective in brainstorming different ideas about writing topics. & 15 & 1.87 & .352 \\
\hline 19 & The CLL approach could help low level students develop their writing skills. & 15 & 1.60 & .632 \\
\hline 20 & The CLL approach enhances spelling. & 15 & 1.60 & .737 \\
\hline 21 & The CLL approach enhances punctuation. & 15 & 1.67 & .724 \\
\hline 22 & The CLL approach enhances grammar. & 15 & 1.40 & .828 \\
\hline 23 & The CLL approach enhances the narrative technique in writing & 15 & 1.33 & .816 \\
\hline 24 & The CLL approach gives a very good chance to get useful feedback. & 15 & 1.80 & .414 \\
\hline 25 & The CLL approach creates more supporting ideas in writing an essay. & 15 & 1.60 & .632 \\
\hline 26 & The CLL approach develops problem-solving technique. & 15 & 1.20 & .862 \\
\hline 27 & The CLL approach makes writing more enjoyable. & 15 & 1.40 & .828 \\
\hline 28 & The CLL approach helps in doing more than one task. & 15 & 1.00 & .926 \\
\hline 29 & The CLL approach develops revision as well as checking skills & 15 & 1.33 & .816 \\
\hline 30 & The CLL approach develops the skill of paragraph planning. & 15 & 1.33 & .900 \\
\hline 31 & The CLL approach makes writing easier. & 15 & 1.53 & .743 \\
\hline 32 & The CLL approach creates an atmosphere of achievement. & 15 & 1.47 & .743 \\
\hline 33 & The CLL approach creates a friendly atmosphere of learning. & 15 & 1.87 & .352 \\
\hline 34 & The CLL approach makes writing more funny and interesting. & 15 & 1.67 & .724 \\
\hline \multicolumn{2}{|r|}{ The General Mean } & \multicolumn{3}{|c|}{1.48} \\
\hline
\end{tabular}

The previous results showed that the participants in the current study agreed on the items included in the attitude questionnaire with a mean equal to 1.48 out of 2.00 . This percentage belongs to the third category in the three-level Likert scale. It referred to the students' acceptance of using the CLL approach to enhance their writing skills. The rate of acceptance ranged from 1.00 to 1.87 . This rate belongs to the second and the third category of the three-level Likert scale (which refers to agree or neutral) respectively. In general, item 28 (The CLL approach helps in doing more than one task.) came last in the order of acceptance as the mean of its acceptance reached 1.00 out of 2.00 while item 18 (The CLL approach is effective in brainstorming different ideas about writing topics.) came first with 1.87 mean of acceptance out of 2.00. Such previous results highlighted the close relationship between the CLL approach and brainstorming as students had more freedom to brainstorm new ideas through working together within one group. Each one of them felt responsible for achieving their purpose of getting enough ideas that could help them write an essay successfully so that they could be classified as the best group inside the class. As for Item 28 which came last, it was obvious that students did not want to achieve their tasks quickly. They wanted to take their full time to produce an effective academic writing. They also stated that working together did not allow them to do more than one task as they spent some time discussing and talking. The results also showed that students were impressed and happy because of the supportive environment provided through working with peers in a group. The English writing class became more interesting as most students could work with more relaxation and fun. Although the students were worried about their low writing skills at the start of the treatment, they gradually became more confident and didn't fear making mistakes because they considered the activities encouraging and motivating. However, students still made mistakes in their writing especially in spelling and grammar. The researcher had to intervene when students wanted to be sure about their spelling or structures so that they could benefit from such feedback to develop their spelling and grammatical skills. The selected activities included in the CLL approach helped students benefit from their participation in the small groups and they found them valuable and useful to enhance their writing skills and develop positive attitudes towards using it inside the class.

\section{DISCUSSION AND CONCLUSION}


The findings of the study supported the use of the CLL approach to enhance students' EFL writing skills. The reason why their score in the post-test increased was probably due to the opportunities provided by this approach for students of different levels to support, encourage, and give feedback to each other. The use of this approach creates more interesting, comfortable, and funny learning environment in which students could share and exchange ideas to achieve their intended purpose. The significant improvement on the students' EFL writing skills might have resulted from the processes that students experience while working together in small groups. These processes included brainstorming, discussing, thinking, planning, drawing an outline, and finding solutions to certain problems in a group instead of doing such processes individually or in a whole class context. The findings related to the effectiveness of using the CLL approach to improve students' writing skills were supported by other studies. (Lapsopa, 2005; and Al-Najjar, 2012). The findings related to the need for providing a more relaxed learning atmosphere to students fostered the findings of Mariam's (2004) Adams' (2000) and Ahmed's (2012) that called for concurrent improvement of communication skills.

It is worthwhile mentioning here that the CLL approach provided opportunities for students to share responsibility with regard to writing. Everyone inside each group felt responsible and did his best to fulfill his duty. It can be said that the CLL approach was to some extent effective in developing the social communication between the students as it allowed them to talk and work together. Moreover, it was found that the CLL approach developed the students' ability of giving feedback concerning the mistakes they made in their writing, whether they were in spelling, punctuation, grammar, or organization.

When using the CLL approach inside writing classroom, students felt that they became more responsible for their work as creators of ideas and builders of meaning and knowledge. They worked together, discussed and exchanged ideas in a more interactive and learner-centered environment. They felt they became autonomous learners as they found themselves engaged in doing different types of writing tasks without much help from the lecturer. These findings were in line with a number of studies that were carried out in the same field. (Astin, 1993; Ellison \& Boykin, 1994; Elola \& Oskoz, 2010; Barkley et al. 2005) Moreover, the students had positive attitudes towards using the CLL approach to enhance their communication skills, critical thinking skills, and motivation. Using the CLL approach made writing enjoyable, meaningful, motivating, relevant, and reduces anxiety as students interact with each other in interesting groups. Such findings went with others obtained in similar areas. (Millis, B. J., \& Cottell, P. G., 1998, Barkley et al., 2005; Nor \& Abd. Samad, 2003).

As for the problems and the challenges that the researcher faced while applying this study, it was noted at the start of the application of the CLL approach that some students did not appreciate the use of it at the start of the treatment. The lack of motivation to work in small groups might due to two main reasons; one of them was related to the weak level students who felt that they might be negatively absorbed in group activities and also feared of making mistakes in front of their friends, the second reason was related to good level students who felt that they were much more competent than low level ones and working in groups would make them out of focus. Some of them expressed their refusal to work in groups but they gradually changed their opinions when the steps of the procedures were explained to them by the researcher in the first lecture. However, it must be stated that some students complained that members in their groups were somewhat inactive as well as indifferent when one of the group wanted to do the whole task or when members of the group found that a good chance to them to do nothing. Another problem arose when the students lacked ideas about the topic they were going to write about. The researcher took the role of a facilitator and tried to help them by suggesting some helpful points that might help them brainstorm more ideas and decide on the main outline of their writing. Sometimes the absence of one member of any of the five groups made a kind of disturbance to the whole work, but the researcher tried to overcome this problem by giving this group less work or work with this group as a group member not as a lecturer.

In sum, the findings of this study confirmed that the use of the CLL approach had a positive impact on developing students' writing skills but more attention should be paid to conduct the activities in an effective planned and designed way. Needless to say, then, while using the CLL approach, the number of students in each group ought to be limited to three four or five. From the researcher's point of view, each group should be allowed to choose their partners in the group as well as their leader so that they could avoid unnecessary talk and time wasting. They could also work effectively together so as to develop and enhance their EFL writing skills.

\section{RECOMMENDATIONS}

Based on these results, the current study recommended using the CLL approach as an essential component in any university writing course. Lecturers should offer students more stimulating and enjoyable learning environment through providing them with interesting co-operative learning activities that are challenging and attractive to all of them. The benefits and drawbacks of using the CLL approach to enhance EFL writing skills need to be assessed and evaluated with a large number of students so that more comprehensive details could be provided.

APPENDiX A. WRITING TEST

(1) Yung Sheen has special memories and feelings about his wedding suit (Kimono). Write about a piece of clothing that is special to you. (5 marks) 
What does it look like?

Why is it important to you?
How did you get it?

How does it make you feel?

(2) Read the following paragraph and correct the three fragments and two run-on errors. Do not forget to use appropriate punctuation and capitalization. (5 marks)

My father's nephew owned a factory, and I worked there as a young man. I enjoyed this work very much. Saw a large number of people. One time a new worker came to work with us in the factory. He a son, he was my age. We met often and talked about our work. I invited him to meet my family. He told us about his life in Qatar. We enjoyed our time. Suddenly, my dad told him something unforgettable. He said, "I know that you want to marry again." My father an intelligent man, he was right. The man came to this place not to look for work but to work for a wife.

(3) Write two supporting sentences for each of the following topic sentences. (8 marks)

1. Computers are useful in many ways.

2. There are certain characteristics that I always look for in a good hotel.

3. When I want to look nice for a party, I follow a few simple steps.

4. There are many ways to show respect for older people.

(4) Read the following paragraph below on "Buying a Sofa", cross out the sentences that do not support the topic sentence. (5 marks)

My aunt acquired a new sofa in an unusual way. She was walking to the train station, and she saw a yard sale. A family was selling a beautiful but old blue sofa at a very good price. She examined it and found it in a good state. She decided to buy it but there was a problem. She did not have a truck and her apartment was far from this place. Suddenly, she saw my father in his truck and asked him to help her. He was always helpful. He was tall with a long bear and glasses. She paid for the sofa and my father carried it and put it in the truck. It was a heavy truck. Its color was red with white lines. He bought it last year. One of his friends helped him to get it. My aunt and my father took the sofa home. On the way, they drank some coffee and ate sandwiches. They were delicious.

(5) Write a thesis statement, describing the three categories for each of these topics. Use the classification expressions below. (6 marks)

1. Topic: Teachers friendly, unfriendly, indifferent

2. Topic: Friends childhood friends, friends from school, friends from work

(6) A good college should allow students to develop in many ways: academically, socially, and culturally. Do you agree or disagree? To what extent does your college provide these opportunities? Write a three-paragraph essay expressing your opinion. (8 marks)

(7) Read the following paragraph and answer the questions below it. (4 marks)

Ethanol can be produced from the fermentation of some crops that contain starch, wheat, sugar cane, and, in Indonesia, sweet potatoes and especially, cassava. In the process of converting cassava to ethanol, the first step is milling, the reduction of the size of the particles. Next, the particles are cooled; the cassava is hydrated, and its starch gelatinized. Following that way, the starch is converted by enzymic hydrolysis into sugars, and then the ethanol from the sugars, including limited dextrin conversion, is fermented. In the final step, the ethanol is recovered through distillation, and the cassava residues are recovered by evaporation and waste treatment.

1. Why is passive voice used?

2. Change the passive voice in each sentence to active voice, what changes in tone and audience results?

3. Who is the audience for this paragraph? How do you know?

4. Write the chronological connectors?

(8) Read the following sentences. Then number them in the order you think they occurred. Use the sequence words and phrases as clues. (4 marks)

1. A few years ago, my two older brothers and I went trekking in the mountains.

2. Finally, I found the muddy trail, and we made it back to our base camp.

3. Soon we were hiking through thick pine forests.

4. We set out from our base camp on a bright winter morning.

5. After that experience, I realized it is very important to be careful when hiking in the mountains.

6. A little while later, we stopped to eat, and my older brother said we should turn around because we were losing the trail in the snow.

7. Eventually, it began to snow, and visibility became poor.

8. Going back down the mountain was harder because it was very icy and slippery, and we could not find the way. We became tired, cold and thirsty.

\section{APPENDIX B. QUESTIONNAIRE}

This questionnaire is designed to measure the students" attitudes towards using the CLL approach to enhance the writing skills of second-year students enrolled in EN 211 course in the second semester of 2013 academic year at Al Imam University, College of Languages and Translation. The questionnaire is divided into two parts that you must read carefully, check and respond to the items included in each one of them.

Your answers will be kept strictly confidential and anonymous. 


\section{Part One}

Please, tick the appropriate box.
A. Current GPA: below 60
$60-69 \quad 70-79$
80-89
1. Yes
90 and above
B. Writing is an easy skill to learn.
C. I prefer to write alone rather than in a group. 1. Yes

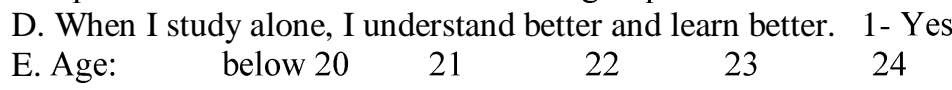
2- No
2- No
2- No

Part Two

Indicate the extent to which you agree or disagree with the following statements regarding your views about using the CLL approach to enhance the writing skills of sophomore students by putting a tick $(\sqrt{ })$ in the appropriate box using the scale given below.

Disagree 0

Neutral 1

Agree 2

\begin{tabular}{|c|c|c|c|c|}
\hline No. & Statement & Agree & Neutral & Disagree \\
\hline 1 & The CLL approach develops students' awareness of writing skills & & & \\
\hline 2 & The CLL approach improves interpersonal and team skills & & & \\
\hline 3 & The CLL approach develops critical thinking skills & & & \\
\hline 4 & The CLL approach gives chances to express ideas freely. & & & \\
\hline 5 & $\begin{array}{l}\text { The CLL approach provides more opportunities for students to participate in hands-on } \\
\text { activities }\end{array}$ & & & \\
\hline 6 & $\begin{array}{l}\text { The CLL approach develops students' responsibility not only for learning what is being } \\
\text { taught, but also for helping teammates learn. }\end{array}$ & & & \\
\hline 7 & The CLL approach assists peers to learn through explaining subject content to one another & & & \\
\hline 8 & The CLL approach saves time & & & \\
\hline 9 & The CLL approach is a very worthwhile experience. & & & \\
\hline 10 & The CLL approach can be used to stimulate students to acquire the knowledge & & & \\
\hline 11 & The CLL approach fosters exchange of ideas, information and experience. & & & \\
\hline 12 & The CLL approach enhances performance in designing and organizing an essay. & & & \\
\hline 13 & The CLL approach should be used in teaching all language skills. & & & \\
\hline 14 & The CLL approach decreases competitiveness and individualism. & & & \\
\hline 15 & The CLL approach increases students' self-esteem. & & & \\
\hline 16 & The CLL approach offers students opportunities to become more intrinsically motivated. & & & \\
\hline 17 & The CLL approach develops the spirit of confidence. & & & \\
\hline 18 & The CLL approach is effective in brainstorming different ideas about writing topics. & & & \\
\hline 19 & The CLL approach could help low level students develop their writing skills. & & & \\
\hline 20 & The CLL approach enhances spelling. & & & \\
\hline 21 & The CLL approach enhances punctuation. & & & \\
\hline 22 & The CLL approach enhances grammar. & & & \\
\hline 23 & The CLL approach enhances narrative technique in writing & & & \\
\hline 24 & The CLL approach gives a very good chance to get useful feedback. & & & \\
\hline 25 & The CLL approach creates more supporting ideas in writing an essay. & & & \\
\hline 26 & The CLL approach develops problem-solving technique. & & & \\
\hline 27 & The CLL approach makes writing more enjoyable. & & & \\
\hline 28 & The CLL approach helps in doing more than one task. & & & \\
\hline 29 & The CLL approach develops revision as well as checking skills & & & \\
\hline 30 & The CLL approach develops the skill of paragraph planning. & & & \\
\hline 31 & The CLL approach develops comprehension skills. & & & \\
\hline 32 & The CLL approach makes writing easier. & & & \\
\hline 33 & The CLL approach creates an atmosphere of achievement. & & & \\
\hline 34 & The CLL approach creates a friendly atmosphere of learning. & & & \\
\hline 35 & The CLL approach makes writing more funny and interesting. & & & \\
\hline
\end{tabular}

\section{REFERENCES}

[1] Adams, I. W. (2000). Exploring the Efficacy of Cooperative/Collaborative learning: The Experience of College ESL Teachers (Doctoral Dissertation, University of New Orleans, 2000). Dissertation Abstracts International, 61 (04), 1271A.

[2] Ahmed, Omnia Nabih. (2012). The Effect of Different Learning Styles on Developing Writing Skills of EFL Saudi Learners. British Journal of Art and Social Sciences, Vol.5, No.2, British Journal Publishing,pp.220-233.

[3] Al-Najjar, Majeda. (2012). Teaching Essay Writing Skills Using Cooperative Learning Approach.: the Case of Princess Alia University College, European Journal of Social Sciences, Vol.35, No.3, November, pp.300-309.

[4] Astin, A. (1993). What Matters in College. San Francisco, CA: Jossey-Bass.

[5] Atkinson, D. (2003). L2 Writing in the Post-Process Era: Introduction. Journal of Second Language Writing 12, 3-15.

[6] Barkley, F. E, Cross, K. P \& Major, C. H (2005) Collaborative Learning Techniques: A Handbook for College Faculty. JosseyBass: WILEY

[7] Biggs, J. (1999). What the Student does: Teaching for Enhanced Learning. Higher Education Research \& Development, 18, pp.57-75.

[8] Brookfield, S. D., \& Preskill, M. S. (1999). Discussion as a way of teaching: Tools and techniques for democratic classrooms. San Francisco: Jossey-Bass. 
[9] Brown, F. (2008). Collaborative Learning in the EAP Classroom: Students" Perceptions. (Retrieved 10th June 2011) http://pdffinder.net/ Collaborative-Learning-in-the-EAP Classroom:-Students'-Perceptions/

[10] Budd, W. J. (2004). Mind maps as classroom exercises. Journal of Economic Education V35,pp. 35-46/

[11] Chandrika, N., (2001). The effectiveness of cooperative learning in a Form One TESL writing classroom. Unpublished bachelor's degree dissertation, Universiti Pendididkan Sultan Idris, Tanjong Malim, Perak, Malaysia.

[12] Chen, M. L. (2004). A study of the Effects of Cooperative Learning Strategies on Student Achievement in English as a Foreign Language in a Taiwan College. New York: ProQuest Information and Learning Company.

[13] Cole, Karen Sanderson.(2012). Promoting Cooperative Learning In An Expository Writing Course. Journal of International Education Research - Second Quarter, Volume 8, Number 2,pp.113-124

[14] Depaz, I. \& Moni, R. W. (2008). Using peer teaching to support co-operative learning in undergraduate pharmacology, School of Biomedical Sciences Educational Research Unit, The University of Queensland, Brisbane. Retrieved from http://www.bioscience. heacademy.ac.uk.journal /vol11/beej-11-8.aspx/

[15] Ellison, C.M., \& Boykin, A.W. (1994). Comparing Outcomes from Differential Cooperative and Individualistic Learning Methods. Social Behavior and Personality, 22, 91-104.

[16] Elola, I., and Oskoz, A. (2010). Collaborative Writing: Fostering Foreign Language and Writing Conventions Development. Language Learning \& Technology. Retrieved from http://ltt.msu.edu/vol14num3/ elolaoskoz.pdf October 2010, Vol 14, (3), pp. 51-71

[17] Farrah, M.A. Hakim. (2011). Attitudes Towards Collaborative Writing Among English Majors in Hebron University, Arab World English Journal, Vol.2 No. 4 December, pp. 136-170

[18] Gleason, M. M., \& Isaacson, S. (2001). Using the New Basal to Teach the Writing Process: Modifications for Students with Learning Problems. Reading \& Writing Quarterly, 17, 75-92.

[19] Hayashi, C. (2005). Scaffolding the Academic Writing Process: A Focus on Developing Ideas. Paper Presented at Lifelong Learning: Proceedings of the 4th Annual JALT Pan -SIG Conference. Tokyo, Japan: Tokyo Keizai University.

[20] Herreid, C. F. (2006). Using Case Studies to Teach Science. Action Bioscience. Retrieved August 12, 2010, from www.actionbioscience.org/ education/herreid.html.

[21] Hirst, L. A. \& Slavik, C. (2005). Effective Language Education Practices and Native Language Survival. In J. Reyhner (Ed.), Native American Language Issues (pp. 133-142). Choctaw, OK: NALI Board of Executors.

[22] Johns, Ann M. (1997). Text, Role, and Context: Developing Academic Literacies. Cambridge Applied Linguistics Series, Cambridge University Press, the Press Syndicate of the University of Cambridge, the Pitt Building, Trumpington Street, Cambridge CB2 IRP, United Kingdom.

[23] Johnson, D.W. and Johnson, R.T. (1998). Cooperative Learning and Social Interdependence Theory. Social Psychology Applications to Social Issues. Retrieved December 27, 2005, from http://www.cooperation.org /pages/ SIT.html.

[24] Johnson, D. W., Johnson, R. T., \& Holubec, E. J. (1995). Circles of Learning. (4th ed.). Edina, MI: Interaction Book Company.

[25] Kagan, S.(1994). Cooperative Learning. (San Clemente, Kagan Cooperative Publishing).

[26] Kagan, Spencer. (2003). A Brief History of Kagan Structures. Kagan Online Magazine. (Summer). www.kaganonline.com/ KaganClub/ Free Articles.

[27] Kim, Y. \& Kim, J. (2005). Teaching Korean University Writing Class: Balancing the Process and the Genre Approach. Asian EFL Journal, Vol. 7(2). Retrieved from http://www.asian-efl-journal.com /June_05_yk\&jk.pdf

[28] Lapsopa, Benja. (2005). A study of English Reading and Writing Achievement of Sixth Grade Students Taught by the Cooperative Learning Approach. M.A. Thesis, Silapakorn University.

[29] Lee, 2003; Lee, C.C. (2007) Graphic Organisers as Scaffolding for Students' Revision in the Pre-Writing Stage, Nanyang Technological University. Retrieved from http:// www.ascilite.org.au /conferences/ singapore07/procs/lee-cc.pdf. www.ascilite. org.au/conference/ singapore07/procs/lee-cc.pdf. Accessed on 18 December 2008.

[30] Mariam M. Nor, (2004). A Qualitive Study of Group Writing During Process Writing Lessons. (Unpublished doctoral dissertation). Universiti Malaya, Kuala Lumpur, Malaysia.

[31] Millis, B. J., \& Cottell, P. G., (1998). Cooperative Learning for Higher Education Faculty. Phoenix, AZ: American Council on Education and The Oryx Press.Nor \& Abd. Samad, 2003.

[32] White, A. S., \& Caminero, R. (1995). Using Process Writing as a Learning Tool in the Foreign Language Class. The Canadian Modern Language Review, 51(2), 323-329).

[33] Wong, L.-H., Chin, C.-K., Chen, W. \& Gao, P. (2009). An Innovative Collaborative Writing Approach to Improve Chinese as L2 Pupils" Linguistic Skills. Proceedings of International Conference on Computer-supported Collaborative Learning (pp.651-661), Rhodes Island, Greece. (Retrieved 15th May 2011) http://lhwong.home.nie.edu.sg/CSCL09-wiki_writing.pdf.

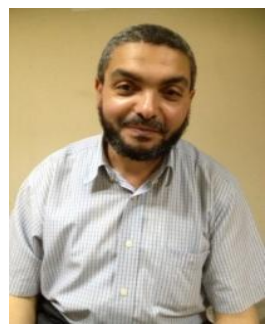

Montasser Mohamed AbdelWahab Mahmoud, PhD in TEFL; An Assistant Professor at Al-Imam University, College of Languages and Translation, Riyadh, Saudi Arabia; A Lecturer at Al-M'aref Higher Institute of Languages and Translation, Cairo, Egypt; A Member of Al-Harmain Translation Team Project. A Reviewer at the International Education Studies, Canadian Centre of Science and Education; A reviewer at the BERJ British Educational Research Journal; A Reviewer at the IOSR Journal of Research \& Method in Education (IOSR-JRME). 